\title{
GALC Gene
}

National Cancer Institute

\section{Source}

National Cancer Institute. GALC Gene. NCI Thesaurus. Code C121621.

This gene plays a role in hydrolysis of galactose ester bonds. 